\title{
Investment Strategies For Tax Diversification: Don't Put All Your Eggs In One Tax Basket
}

\author{
J. David Ashby, Southern Arkansas University, USA \\ Darla G. Williams, Mustard Seed Financial LLC, USA \\ Terrye A. Stinson, Southern Arkansas University, USA
}

\begin{abstract}
Traditional analysis on the use of Roth accounts often focuses on the expectations of tax rates in the future. However, tax diversification into tax-free accounts such as the Roth accounts may make sense independent of expectations regarding future tax rates. This is due to the taxation of Social Security benefits and the laws relating to required minimum distributions for traditional retirement accounts. Many taxpayers may find their overall income tax burden lighter in the retirement years by making use of taxable, tax deferred and tax-free investment accounts.
\end{abstract}

Keywords: tax planning, Roth IRA, tax diversification, retirement planning

\section{INTRODUCTION}

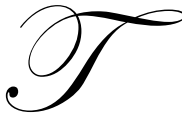

he concept of asset diversification to reduce risk is well established in the financial literature. Assuming that the goal of investors is to minimize after tax returns on the portfolio consistent with their level of risk tolerance, investors should also consider tax diversification.

There are basically three different tax classifications for investment accounts: taxable accounts, taxdeferred accounts, and tax-free accounts. Taxable accounts include savings accounts, CDs, and non-retirement mutual fund accounts. Tax-deferred accounts include deductible IRA's and 401(k) type accounts. Tax-free accounts include municipal bonds, Roth IRA's and Roth 401(k) and 403(b) accounts. According to Grote (2007), experts concur that future tax rates are uncertain and investors need different strategies for retirement planning.

Conventional wisdom advises investors to delay taxes as long as possible into the future, making the taxfree Roth plans attractive investments. When considering the potential tax saving afforded by a Roth-type plan, an individual evaluates the tax savings is based on (1) the laws regarding taxation of Social Security benefits, and (2) the rules regarding required minimum distributions of tax deferred accounts. These considerations need further analysis. This paper presents a brief discussion of the traditional argument for funding or not funding Roth accounts based on expectations of future tax brackets. Then, independent of future tax rates, this paper presents an example of a tax diversified portfolio that includes taxable, tax deferred and tax-free accounts that demonstrates the resulting tax savings in retirement.

\section{REVIEW OF LITERATURE}

Investment decisions for retirement and estate planning purposes take into consideration the cash-flow needs of the individual and the anticipated tax impact of investment alternatives. Since the late 1970s, federal laws have significantly shaped investment decisions.

Employees typically choose pension plans following one of two income tax approaches. Under the most common plan, an employee's contribution to the retirement plan is excluded from income (a pre-tax exclusion). 
These plans, typically 401(k) or 403(b), were created by the Revenue Act of 1978. In contrast, a traditional IRA follows an alternate income tax approach. An employee who is not covered by an employer's plan may contribute to a traditional IRA and is allowed a deduction for AGI. Under either approach, the employee-investor is not taxed until distributions occur. Self-employed individuals may also establish similar tax-deferred retirement accounts. (IRS, 2008a)

The Tax Relief Act of 1997 (Public Law 105-14) created the tax-free Roth IRA account for individual investors. Birrer (2006) summarized the key advantages of a ROTH IRA for retirement and estate planning: tax-free distributions and the absence of minimum distribution requirements for investors. While these are significant advantages, the Roth IRA has two drawbacks. One, full contributions in 2009 are restricted to those with an AGI of $\$ 166,000$ or less (married filing jointly) and $\$ 105,000$ or less (single taxpayers), and most married taxpayers filing separate returns cannot contribute to a Roth IRA. Two, contributions to a Roth IRA in 2009 are limited to $\$ 5,000$ per individual plus a $\$ 1,000$ catch-up contribution for those aged 50 and over. (IRS, 2008b)

Beginning in 2006, the Economic Growth and Tax Relief Reconciliation Act (EGTRAA) added another options by allowing employers to establish a Roth $401(\mathrm{k})$ as an employee retirement benefit option. While offering tax-free advantages similar to the Roth IRA, the Roth 401(k) also allows contributions regardless of the individual's AGI and allows higher contributions. In 2009, an individual can contribute up to $\$ 16,500$ plus a $\$ 5,500$ catch-up contribution for those aged 50 and over. Caudill (2005) explains that this is a combined limit encompassing total contributions to both a traditional 401(k) and Roth 401(k). (IRS, 2009)

While the tax-free Roth accounts offer significant tax savings potential, Nessmith and Utkus (2007) report slow adoption of the Roth $401(\mathrm{k})$ by companies and even slower adoption by employees. In 2006, the first year that the Roth 401(k) was available, the Roth option was adopted by only 14\% of Vanguard plans. Further, only 5\% of participants within the plan elected the Roth option. Both employers and participants may be missing important tax planning opportunities in this area.

\section{THE UNCERTAINLY OF INCOME TAX RATES AFTER RETIREMENT}

Traditionally, financial planners assume that clients will be in a lower tax bracket upon retirement. This was a logical assumption given the progressive nature of the U.S. tax code, inflation adjusted tax brackets and targeted income levels in retirement of 60 to 80 percent of pre-retirement income (McQuarrie, 2008). A person making $\$ 50,000$ per year at retirement could normally be assumed to need somewhere between $\$ 30,000$ and $\$ 40,000$ per year after retirement. The lower income needed in retirement is justified for several reasons. For example, Social Security taxes are not paid on investment income or retirement income. In addition, the costs associated with working, such as commuting, are reduced. A lower level of income reduces the absolute amount of taxes paid and may often reduce the marginal bracket as well. So, for a variety of logical reasons, the assumption of a lower tax bracket has often been advanced. Increasingly, however, the assumptions about future tax rates are becoming uncertain. Lower taxes in retirement are not guaranteed.

A number of factors contribute to uncertainty about future tax rates. Increases in the budget deficit, for example, may create pressure on tax rates. Prior to the financial meltdown of 2008 , the U.S was on track to run a budget deficit of $\$ 480$ billion. Once the 2008 meltdown occurred, stimulus and bailout packages have pushed the projected deficit to more than $\$ 1.8$ trillion. Other factors, such as the financial problems surrounding Social Security, Medicare, and a possible national health care system, also create a scenario where tax rates are more likely to increase than decrease.

Given the increasing uncertainly about future tax rates, an investor faces a real challenge to determine the best portfolio that addresses both asset diversification and tax diversification. Upon retirement, the investor could face higher taxes even though the retiree's income is only 60 to 80 percent of wages before retirement. Today's tax rate structure is relatively low, but many upper income retirees may find their largest expense to be income taxes. To minimize taxes in retirement, retiree's portfolios should include a mix of taxable, tax-deferred and tax-free accounts. Ahern et. al. (2005) conclude that cumulative changes in the tax rates have eliminated the conventional theory that pre-tax investments are always the best tax strategy for retirement. 


\section{Taxable Accounts}

Taxable accounts are generally funded with after-tax dollars. Thus, there is no income tax advantage on the front end to funding these accounts. Furthermore, income generated by taxable accounts is currently includible in this year's tax return. In return for these tax disadvantages, however, taxable accounts normally have a high tax basis. Such accounts, therefore, represent a tax-efficient source of cash for living expenses and large non-recurring purchases during retirement, such as major vacation, home remodel, etc.

\section{Tax-deferred Accounts}

Contributions to traditional tax-deferred accounts such as deductible IRA's or 401(k)'s provide current income tax relief. Thus, the contributions are effectively subsidized by the taxing authorities. In addition, the earnings on such accounts are tax-deferred until withdrawn. In return for these advantages, there are drawbacks. For one, all income withdrawn from these accounts is subject to ordinary income tax rates, plus at age 70.5 the retiree must take required minimum distributions (RMD), which are taxed at ordinary rates. The RMD are required regardless of whether or not the retiree needs the funds.

\section{Tax-free Accounts}

Tax-free accounts include municipal bonds and Roth accounts. Income limitations prohibit many individuals from participation in Roth IRAs. However, Roth 401(k) and Roth 403(b) options became available in 2006. The income limitations that apply to the Roth IRA do not apply to the Roth 401(k) and Roth 403(b) accounts. While they provide no current income tax relief for current contributions, Roth accounts have the advantage of taxfree earnings for qualified withdrawals. This provides some insulation from higher tax rates in the future at the cost of a lost deduction currently.

The decision as to whether or not one should contribute to a Roth account has often been framed in terms of current and expected tax rates.

- If tax rates are expected to be lower in the future, a traditional tax deferred retirement account is better and provides the individual with a current deduction. An individual in a 35\% bracket today may prefer a current tax deduction if he expects to be paying taxes at $20 \%$ after retirement.

- If tax rates are expected to be higher in the future, the Roth account may be a better choice because it will allow the individual to take tax-free distributions in the future.

- If tax rates are expected to remain constant, Birrer (2006) shows that it makes no difference whether the Roth or a traditional tax deferred retirement account is funded. The after tax results are the same.

The choice between a Roth IRA and a traditional IRA, however, may go beyond the expectation of future tax rates. The example below demonstrates the logic of tax diversifying independent of future tax rate considerations. The key factors driving this argument are (1) the taxation of Social Security and (2) the required minimum distributions from tax-deferred retirement accounts

\section{TAXATION OF SOCIAL SECURITY}

Taxation of some Social Security benefits also impacts the choice between available retirement investments. Under current law, Social Security benefits to retirees become taxable once income levels exceed certain limits. The income test is based on modified adjusted gross income (MAGI). For single taxpayers, if MAGI is under $\$ 25,000$ none of the Social Security benefits need be included in taxable income. When MAGI exceeds $\$ 25,000$, Social Security benefits begin to be partially taxable. For MAGI in the range of $\$ 25,000$ to $\$ 34,000,50 \%$ of Social Security benefits may be included in taxable income. When MAGI exceeds $\$ 34,000,85 \%$ of Social Security benefits may be included in taxable income. For married taxpayers, the MAGI brackets are $\$ 32,000$ to $\$ 44,000$. 
Modified adjusted gross income is calculated by adding certain items to an individual's adjusted gross income (AGI) as calculated prior to the inclusion of any Social Security benefits. The formula is given in Table 1 below.

\begin{tabular}{|l|ll|}
\hline \multicolumn{3}{|c|}{ Table 1: Calculation of Modified Adjusted Gross Income } \\
\hline Adjusted Gross Income & + & one half of Social Security benefits received \\
\hline & + & municipal bond interest that was previously excluded \\
\hline & + & U.S savings bond interest that was previously excluded \\
\hline & + & foreign earned income and housing allowances that were previously excluded \\
\hline & + & student loan interest that was previously deducted \\
\hline & + & domestic production activities that were previously deducted, and \\
\hline & + & $\begin{array}{l}\text { income from Guam, American Samoa, the Northern Marianna Islands and Puerto Rico } \\
\text { previously excluded. }\end{array}$ \\
\hline
\end{tabular}

Note that the adjustments include interest from bonds that is considered non-taxable but does not consider qualified distributions from Roth accounts. The potential taxation of Social Security benefits, therefore, affects the choice between tax-free investments.

\section{REQUIRED MINIMUM DISTRIBUTIONS}

Taxation of required minimum distributions from some retirement investments also impacts the choice between available retirement options. With a traditional tax-deferred retirement account, the IRS requires that an individual begin withdrawing funds from the investment account upon reading the age of 70.5. These withdrawals, referred to as required minimum distributions (RMD), are based on the life expectancy of the person. The individual must take the first RMD by April 1 of the year following the year that the individual reaches age 70.5. Thereafter, the individual must take a RMD each year. RMDs are generally fully taxable and taxed as ordinary income. The RMD rules apply to all types of tax deferred retirement accounts (profit sharing, 401(k), 403(b), and traditional IRA). The RMD rules also apply to a Roth 401(k) and Roth 403(b) accounts, but do not apply to Roth IRAs. To avoid the RMD rule on a Roth 401(k) or Roth 403(b) account, an individual may elect to roll such accounts into a Roth IRA in a nontaxable rollover.

\section{THE ADVANTAGE OF TAX DIVERSIFICATION - A WORKING EXAMPLE}

The combined factors of Social Security taxation and required minimum distributions make tax diversification of the portfolio a prudent move for many investors. The case below provides an example that illustration the advantages of tax diversification in retirement planning.

\begin{tabular}{|c|}
\hline Tax Diversification Case \\
\hline $\begin{array}{l}\text { David and Judy are a married couple; both are age } 70 . \text { They have a } \$ 1 \text { million portfolio from which they draw as needed to } \\
\text { supplement living expenses. Their annual living expenses are approximately } \$ 50,000 \text {. The couple collects } \$ 30,000 \text { per year in } \\
\text { Social Security and takes the standard deduction on their return. }\end{array}$ \\
\hline $\begin{array}{l}\text { - The couple's portfolio has a 50/50 fixed income/equity allocation. } \\
\text { - } \quad \text { Fixed income earns } 5 \% \text { per year and equities earn } 10 \% \text { per year. } \\
\text { - The } 10 \% \text { equity return is comprised of } 3 \% \text { qualified dividends, } 3 \% \text { realized capital gains, and } 4 \% \text { unrealized capital } \\
\text { gains. }\end{array}$ \\
\hline $\begin{array}{l}\text { To illustrate the advantages of tax diversification, presume that the couple had invested based on one of the following } \\
\text { strategies. Based on that strategy, calculate the couple's tax liability using } 2009 \text { tax rates. } \\
\text { - Strategy \#1: 100\% of portfolio invested in taxable accounts } \\
\text { - Strategy \#2: 50:50 investment in taxable accounts and tax-deferred accounts. } \\
\text { - Strategy \#3: One-third investment each in taxable, tax-deferred and tax-free accounts. }\end{array}$ \\
\hline
\end{tabular}




\section{Strategy \#1: All Taxable Accounts}

The results of Strategy \#1 are summarized in Table 2 on the following page. As shown, when the portfolio is held in all taxable accounts, gross income is $\$ 85,000$, taxable income is $\$ 59,600$, and the couple has a tax liability of $\$ 5,105$. At this level of income, $85 \%$ of Social Security is taxable, and $15 \%$ of Social Security $(\$ 4,500)$ is excluded from taxable income. In addition to the maximum Social Security taxation, this strategy produces the highest level of interest income, taxed at ordinary rates. This strategy produces the highest level of dividends and capital gains, even though these items are taxed at capital gains rates.

\section{Strategy \#2: 50\% Taxable: 50\% Tax-Deferred Accounts}

The results of Strategy \#2 are summarized in Table 2 on the following page. As shown, when the portfolio is divided between taxable and tax-deferred accounts, gross income is $\$ 75,500$, taxable income is $\$ 44,625$, and the couple has a tax liability of $\$ 4,359$. With this strategy, the couple must take a required minimum distribution of $\$ 18,000$. Since this is less than the taxable income generated by the all-taxable account strategy, gross income is reduced by $\$ 9,500$. This produces a favorable situation for Social Security, with the couple now able to exclude $\$ 9,975$ in benefits and reduce taxable income overall by $\$ 14,975$. Strategy $\# 2$ results in a tax savings of $\$ 746$ compared to Strategy \#1. One might expect a greater reduction in taxes due, but the tax-deferred account creates ordinary income from the RMD, and there is a corresponding reduction in tax-favored capital gains and qualified dividends. In practice, assets could perhaps be more favorably allocated by holding more fixed income investments (over 50\%) in the tax deferred accounts and holding more equities in the taxable accounts.

\section{Strategy \#3: One Third Each Taxable, Tax-Deferred and Tax-Free}

The results of Strategy \#3 are summarized in Table 2 below. As shown, when the portfolio is divided equally between taxable, tax-deferred, and tax-free accounts, gross income is $\$ 60,333$, taxable income is $\$ 16,566$, and the couple has a tax liability of $\$ 1,157$. This strategy provides maximum tax reduction for this couple for several reasons. First, the RMD is reduced by holding less of the portfolio in the tax-deferred account. Second, income flowing through from taxable accounts is reduced since two thirds of the portfolio is now held in tax favored accounts, either tax deferred or tax free. Finally, Social Security taxable benefits are reduced to a minimal level due to the drop in other income. Strategy \#3, the fully tax diversified portfolio, therefore, produces a tax liability that is 77\% less than Strategy \#1 and 73\% less than Strategy \#2.

\begin{tabular}{|l|c|c|c|}
\hline & $\begin{array}{c}\text { Table 2: Comparison of Investment Strategies } \\
\text { 100\% Taxable Accounts }\end{array}$ & $\begin{array}{c}\text { Strategy \#2 } \\
\text { Taxable and Tax- } \\
\text { Deferred Accounts }\end{array}$ & $\begin{array}{c}\text { Strategy \#3 } \\
\text { Taxable, Tax-Deferred } \\
\text { and Tax-Free Accounts }\end{array}$ \\
\hline Interest Income & $\$ 25,000$ & $\$ 12,500$ & $\$ 8,333$ \\
\hline Qualified Dividends & 15,000 & 7,500 & 5,000 \\
\hline Realized Capital Gains & 15,000 & 7,500 & 5,000 \\
\hline Social Security-Gross & 30,000 & 30,000 & 30,000 \\
\hline RMD & 0 & 18,000 & 12,000 \\
\hline & & & 60,333 \\
\hline Gross Income & 85,000 & 75,500 & 22,867 \\
\hline Less: Social Security Exclusions & 4,500 & 9,975 & 37,466 \\
\hline Adjustable Gross Income & 80,500 & 65,525 & 13,600 \\
\hline Standard Deduction & 13,600 & 13,600 & 7,300 \\
\hline Personal Exemptions & 7,300 & 7,300 & 16,566 \\
\hline Taxable Income & 59,600 & 44,625 & 1,157 \\
\hline Federal Tax Liability & 5,105 & 4,359 & \\
\hline & & & $1.9 \%$ \\
\hline \multicolumn{1}{|c|}{ Average tax rate } & $6 \%$ & $5.8 \%$ & \\
\hline
\end{tabular}


As shown in Table 2, each strategy provides gross income that exceeds the couple's annual living expense of $\$ 50,000$. It would, therefore, be prudent for the couple to reinvest surplus cash and minimize the tax impact on gross income. Framed within the assumptions of the case, investments are earning the same rate of return. Variations in the strategies simply alter the level of taxable income. As prudent investors, the couple would minimize the effective tax rate by following the tax diversified Strategy \#3.

\section{CONCLUSION}

The purpose of this paper is not to suggest an optimum allocation strategy for investors but to illustrate the potential benefits of a tax diversified portfolio as it relates to withdrawal strategies in retirement. These benefits are due largely to the taxation rules regarding Social Security and the minimum distribution requirements for traditional tax-deferred retirement accounts. While tax rules regarding each of these issues may change in the future, it is difficult to predict with precision the form such changes may take.

Regardless of tax law changes, however, it makes sense for prudent investors to include taxable, tax deferred and tax-free accounts in their investment plan. With the availability of Roth IRAs and, more recently, Roth 401(k) plans, employees should consider taking advantage of these vehicles to tax diversify their portfolio and minimize their tax burden over the long run. Additional analysis is needed to study the impact of tax diversification on long-term portfolio values, but the short-term results support the use of taxable, tax deferred and tax-free accounts for the retirement portfolio.

\section{AUTHOR INFORMATION}

J. David Ashby, DBA, CFP, CPA, is the Peoples Bank Professor of Economics and Finance at Southern Arkansas University. He directs the financial planning program at SAU, teaches courses in retirement planning, estate planning, and corporate finance, and owns Mustard Seed Financial LLC. Ashby is serving a 3-year term on the Council on Examinations with the Certified Financial Planner Board of Standards and previously served as national co-chair of the CFP Board Job Analysis Task Force. He has published papers in numerous professional journals and won the 2002 Article Award for outstanding paper presented by the CFP Board.

Darla G. Williams, CFP is a Managing Member and Chief Compliance Officer of Mustard Seed Financial, LLC. She earned her BBA from Southern Arkansas University where she received an award for outstanding academic achievement in finance. She taught as an adjunct instructor at Southern Arkansas University for four years. She currently serves on the Board of the United Way of Columbia County and as Treasurer for the Magnolia Lions Club.

Terrye A. Stinson, DBA, CPA, is the L.J. Blanchard Professor of Accounting at Southern Arkansas University. She earned her MBA and DBA from Louisiana Tech University. Her research interests include financial accounting and strategies for effective teaching. She has published in the Journal of College Teaching and Learning; Journal of Learning in Higher Education; Review of Business Information Systems; CLEAR Exam Review; and Ethics and Critical Thinking Journal. Stinson is a member of the AICPA and Arkansas Society of CPAs. She currently serves on the Arkansas State Board of Public Accountancy and the Arkansas Society's Student Education Fund Board.

\section{REFERENCES}

1. Ahern, Michael, John Americks, Joel Dickson, Robert Nestor and Stephen Utkus, Tax Diversification and the Roth 401(k), Vanguard white paper, October 2005.

2. Bernacchi, Ben T., Determining the Proper Starting Balance for Taxable and Tax-Deferred Savings at Retirement, Journal of Financial Planning, pp. 56-62, July 2008.

3. Birrer, G. Eddy, Traditional versus Roth 401(k): A Benefits Analysis, Journal of Personal Finance, pp. 112-118, 2006.

4. Caudill, A.K., Planning for the Roth 401(k) feature, Journal of Financial Services Professionals, pp. 36-38, September 2005.

5. Grote, Jim, To Defer or Not Defer, Journal of Financial Planning, pp. 28-36, December 2007. 
6. Internal Revenue Service, Designated Roth Accounts in 401(k) or 403(b) Plans, September 22, 2009, available at http://www.irs.gov/retirement/article/0,,id=156204,00.html.

7. Internal Revenue Service, Publication 560, Retirement Plans for Small Business, 2008a, available at http://www.irs.gov/publications/p560/index.html.

8. Internal Revenue Service, Publication 590, Individual Retirement Arrangements (IRAs), 2008b, available at http://www.irs.gov/publications/p590.

9. McQuarrie, Edward F., Thinking Again About the Roth 401(k)? Think Again, Journal of Financial Planning, pp. 38-48, July 2008.

10. Nessmith, William A., and Stephen P. Utkus, Early Adoption of the Roth 401(k), Vanguard white paper, April 2007.

\section{NOTES}


NOTES 